\title{
The Impact of Agricultural Productivity on Rural to Urban Migration in Java, Indonesia
}

\author{
Renata Fauzia ${ }^{1}$ dan Seongwoo Lee $^{1}$
}

Diterima : 19 September 2013 Disetujui : 23 Oktober 2013

\begin{abstract}
This paper investigates if the improvement of agricultural productivity will decrease rural to urban migration. Since rural to urban migration occurs due mainly to disparity between urban and agricultural wage, we assume that boosting agricultural income will reduce migration to urban areas. It is hypothesized that increase in agricultural productivity would result in a rise in agricultural wage, and hence income, ceteris paribus, reduces rural-urban migration. The data used in this study is the 2010 provincial statistics in West Java, Central Java, and East Java, Indonesia. The agricultural productivity and migration equations were estimated by using Ordinary Least Squares (OLS). The research findings may offer the suggestion to reduce rural to urban migration by boosting rural income through focusing the policy on agricultural productivity. Enhancing investment in agricultural sector such as increasing the number of subsidized fertilizer, adding agricultural labor and livestock, increasing education of rural people, and utilizing agricultural land resource are expected to increase agricultural output.Thus, it would also minimize the wage differential between urban and rural area.
\end{abstract}

Keywords: Agricultural Productivity, Rural-Urban Migration, Java, Indonesia.

\section{Introduction}

Many studies have examined that rural-urban migration plays an important role in the process of urbanization. United Nation (UN) reported that $65 \%$ of the increasing number of urban population is due to migration and reclassification from rural to urban areas and $35 \%$ is caused by natural growth. Chen, et al. (1996) reported that internal migration accounted for $40.3 \%, 44.1 \%$ and $54.3 \%$ of urban population growth in the developing world during the 1960's, 1970's and 1980's, respectively. In particular, migration of the labor force from rural to urban markets has been a major source of the growth in urbanization.

Rural out-migration is considered a pathway out of rural poverty as the rural peoplewill probably have better opportunities to earn higher income in urban areas. Nevertheless, escaping rural to urban areas does not necessarily guarantee escaping poverty as well. Instead, rural migration also becomes a major contributor to the problem in the destination areas. In the case of Less Developed Countries (LDC), rapid urbanization can give rise to unemployment and poverty in urban areas, along with other problems such as a progressive overloaded houses and social services, increased crime, pollution, and congestion (Zhang and Song, 2003). As the urbanization continued to increase along with the problems caused by the internal migration, many policies have been implemented to reduce the number of rural-urban migration and restrict rural inhabitant to migrate to urban areas.

\footnotetext{
${ }^{1}$ Regional Development Lab. 200-dong, 8219, Kwanak-gu, Daehak-ro, Seoul National University, Seoul, Korea
} 
Among many factors that can trigger migration, such as agricultural mechanization, land conversion, poor living condition in rural areas, natural disaster, etc., economical decision appears to be the most influential factor to migrate to urban areas in many developing countries. According to Harris-Todaro(1970), migration is an economical decision where the individual or household decides to move if there is a higher expected income in the urban areas. Rural inhabitants live mainly by farming which is considered low paid. If there are better options in urban areas which may be financially more rewarding than farming, rural people are very likely to take in the alteration.

As reported by World Bank (2008), rural development is accountable for $80 \%$ of the decline in rural poverty and generates better conditions rather than out-migration of the poor. In line with that, to control rural-urban migration in LDC, Stiglitz(1969) and Byerlee(1974) argued that the best manner is to have policies which aim to increase agricultural productivity through increased agricultural investment. By focusing policy on rural growth, it will alleviate both urban and rural poverty. In addition, policies that do not provide rural inhabitants with viable economic alternatives will likely lead to migration, creating problems of over urbanization in the urban areas. Accordingly, rural development policies should receive greater attention so that those policies can focus on creating more employment and income in rural areas. It can be a positive factor in a country that is heavily dependent on inputs from rural areas.

According to Mellor (2001), theoretically, increasing agricultural production (output) increases incomes for poor farmers who then increase demand for the goods and services produced by the non-farming rural poor. Hence, higher agricultural output stimulates employment in the rural and urban non-farming sectors through both forward and backward linkages (Hanmer and Naschold, 2000). In turn, when rural growth is achieved, it will slow migration to urban areas and lower food prices which will lead to decrease in urban poverty. Agricultural growth, therefore, benefits poor farmers and landless laborers by increasing both production and employment, benefitting both the urban and rural poor through growth in the rural non-farm economy (Thirtle et al., 2003).

This paper investigates the relationship between agricultural output (GRDP) and rural-urban migration in Java, Indonesia, particularly in the regencies and small cities. It is hypothesized that the improvement of agricultural productivity will increase rural income, and will thereby decrease rural to urban migration. In the present study, the author tries to raise the question: Will increase in agricultural output be able to reduce rural-urban migration?

In order to answer this research question, the study estimates two equations: agricultural output and migration models, by using Ordinary Least Square (OLS). Since rural to urban migration and agricultural performance are tied together, this study identifies which agricultural factors have a significant impact on rural to urban migration.

This paper is constructed as follows. It begins with an introduction which expresses the focus of this study. At the second part, it explains the Indonesian problem of rural-urban migration and agricultural productivity. This article then presents a set of equations as a model of agricultural productivity and rural to urban migration. Subsequently, the paper proceeds to the empirical results and the indirect effect of agricultural output on ruralurban migration. Finally, the results of the model can be used to scheme a policy intended to reduce rural to urban migration in Java, Indonesia.

\section{Rural-Urban Migration and Agricultural Productivity in Indonesia}

Urbanization in Indonesia has been greatly increased from time to time as the government placed few restrictions on rural-urban migration. Most of the migration movements consisted of the rural poor moving into the informal sector and urban slums. Rural-urban migration in Indonesia slowed down after the economic crisis in 1998, but 
continued triggering urban population growth (Hugo, 2000) Even though more than half of the population in the country still depends on agriculture, urban sector is becoming more attractive for many people.

In Indonesia, it is estimated that the urbanization process is majorly caused by rural-urban migration. This presumption is based on the declining natural growth of urban population (see Figure 1), the slow alteration (re-classification) of rural areas in becoming urban, and the vigorous economy and development policies which enlarge pull factor to urban areas for rural inhabitants.

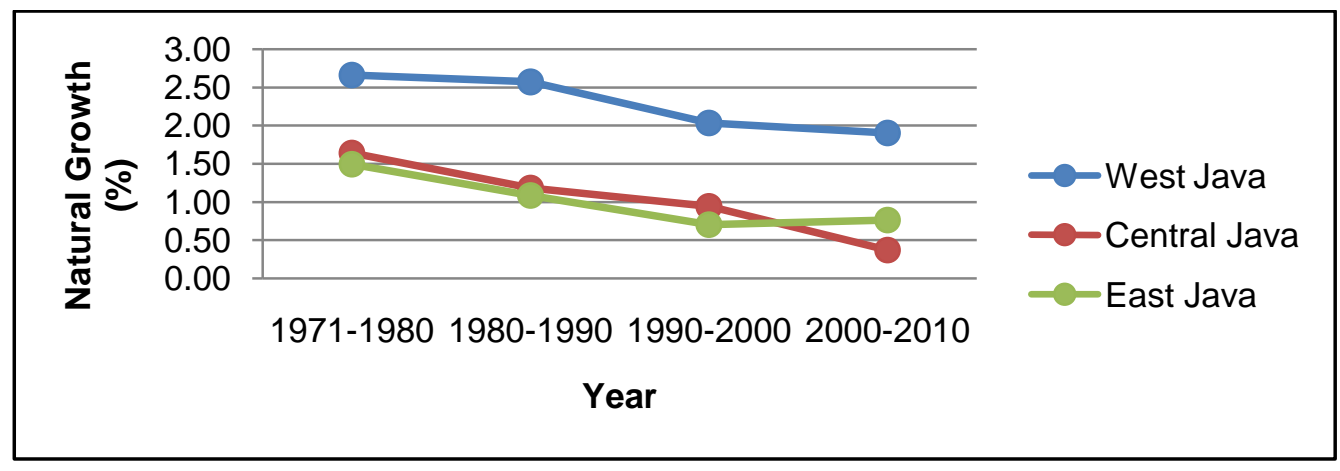

Source: BPS

Figure 1. Natural Growth of Population in West Java, Central Java, and East Java in 1971-2010

In line with the rapid urbanization in those three provinces in Java, the number of in migration also tends to increase over the past decade (see Figure 2). West Java seems to have the highest in migration number compare to other provinces. The increase of migration number leads to the highest number of urbanization rate in West Java. In 2000, West Java has already 55\% urbanized, while Central Java and East Java is $45.5 \%$ and 44.8 respectively. Within a decade, urbanization rate in West Java reached $66.7 \%$ in 2010, while Central Java is $50.3 \%$ and East Java is $50.8 \%$. Thus, it indicates that the increasing number of migration triggers urbanization phenomenon in Indonesia.

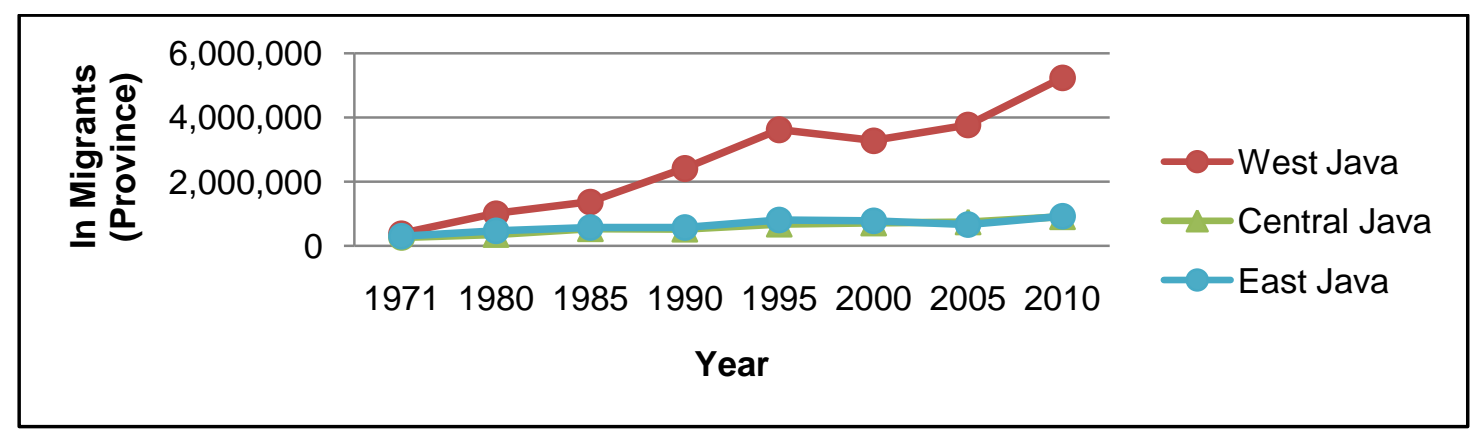

Source: BPS

Figure 2. Trend of Migration in West Java, Central Java, and East Java in 1971-2010

Unsurprisingly, the rapid growth of urbanization is not followed by the growth of agricultural sector. Even though the agricultural output (GDP) in Indonesia had increased during the period 2005-2010, the growth rate has been relatively slow. According to the data from Statistics Indonesia, it is recorded that agricultural GDP growth is the second lowest (after mining and quarrying output growth). During the period 2005-2010, the 
average growth of agricultural GDP is 3.5\% and this is nearly less than a half of the total GDP average growth in Indonesia, which is $5.73 \%$.

As stated by Winoto\&Siregar(2008), the slow growth of agricultural output is conforming to the negative trend occurring in the farmer terms of trade. "Farmer terms of trade" is a proxy to measure peasant welfare. It is defined as the ratio of index of prices received by farmers to index of prices paid by the farmers. Combination of relatively slow growth of agricultural output and the lowered or stagnant farmer terms of trade indicate that farmers' real income has recently been approximately stagnant. It is then highly argued that the stagnancy of agricultural growth is one of the main factors that speeds rural-urban migration and urbanization, with more people concentrated on urban sector economy.

In this research, the estimated rural-urban migration is limited only to urban population who lives in Regency and some small cities and excludes the areas that do not have rural population. While most of the policy discussion concerning urbanization has focused on the growth of megacities and big cities, there has been a little attention to the growing of small cities. While megacities and other cities are facing the huge challenge of coping with the chaos, congestion, pollution and social problems, the newer, smaller urban centers that exhibit all the same problems yet smaller scale has to be dealt with as well. In fact, these small cities often experience worse problems as they are growing disorderly and the required urban amenities are absence (Gosh, 2012). Since the population is increasingly gravitating towards urban areas, the shift has already taken place in many small cities, not only in big cities or megacities. Thus, it is necessary to place more alert on small cities in the coming years as they are growing rapidly.

\section{The Model}

\section{Migration Model}

In explaining migration through macro sense, Harris-Todaro model is often used to capture the urban-rural wage differentials and the probability of getting urban job. Urbanization rate is also included as the independent variable since it is assumed that the higher the number of urbanization is, the greater number of rural people coming in to the urban area. Moreover, urbanization can also affect the number of contacts in urban areas. It is argued that the number of rural inhabitants of the state who would have contacts in urban areas could influence the cost of rural to urban migration. Referring to Bhattacharya (2002), the more urbanized the state is, the greater the number of contacts in urban areas, and such contacts would facilitate migration. Thus, as the state gets more urbanized, it would lower the cost of migration and eventually increase the rural to urban migration rate.

For the migration model, the dependent variable is migration (M). The independent variables are explained by urban population $(\mathrm{Pu})$, rural population $(\mathrm{Pa})$, agricultural output (Ya), urban output $(\mathrm{Ya})$, probability of getting urban job $(\mathrm{P})$, and education in urban areas $(\mathrm{Eu})$.

The migration equation can be written as follows:

$\ln \mathrm{M}=\alpha_{0}+\alpha_{1} \ln \mathrm{Pu}+\alpha_{2} \ln \mathrm{Pa}+\alpha_{3} \ln \mathrm{Ya}+\alpha_{4} \ln \mathrm{Yu}+\alpha_{5} \ln \mathrm{P}+\alpha_{6} \ln \mathrm{Eu}+\mathrm{e}_{\mathrm{t}}$

By replacing the urban/rural population and urban/rural output into agricultural wage $(\mathrm{Wa})$ and urban wage $(\mathrm{Wu})$, and adding urbanization $(\mathrm{U})$ variable, the above equation can be written as:

$\ln \mathrm{M}=\alpha_{0}+\alpha_{1} \ln \mathrm{Wa}+\alpha_{2} \ln \mathrm{Wu}+\alpha_{3} \ln \mathrm{P}+\alpha_{4} \ln \mathrm{U}++\alpha_{5} \ln \mathrm{Eu}+\mathrm{e}_{\mathrm{t}}$

To simplify the model, the wage ratio (WR) is obtained by dividing urban wage (Wu) to agricultural wage $(\mathrm{Wa})$, forming the equation below:

$\ln \mathrm{M}=\alpha_{0}+\alpha_{1} \ln \mathrm{WR}+\alpha_{2} \ln \mathrm{P}+\alpha_{3} \ln \mathrm{U}++\alpha_{4} \ln E u+\mathrm{e}_{\mathrm{t}}$

(3) 


\section{Agricultural Productivity Model}

Cobb-Douglas production function is often used to measure the relationship between inputs and outputs, marginal products, and production elasticity (Dillon and Hardaker, 1993). The log linear form of this function enables quantifying the marginal contribution of each variable of inputs to aggregate production and mitigates the multicolinearity problems. In Cobb-Douglas production function, agricultural output becomes the dependent variable, while the explanatory variables represent the agricultural inputs. Labor, capital, technology, and human capital are included for the independent variables. Capital accumulation is captured by using land and livestock. Fertilizer and tractor are used to measure technical aspect in production. As a proxy for human capital, the level of education is being used.

The dependent variable for this model is agricultural output (Ya), while the independent variables are agricultural land (L), agricultural labor (La), livestock (Li), fertilizer $(\mathrm{F})$, tractor $(\mathrm{T})$, and education in rural areas $(\mathrm{Er})$. The formula for agricultural productivity equation is expressed as follows:

$$
\operatorname{lnYa}=\beta 0+\beta_{1} \ln \mathrm{L}+\beta_{2} \ln \mathrm{La}+\beta_{3} \ln \mathrm{Li}+\beta_{4} \ln \mathrm{F}+\beta_{5} \ln \mathrm{T}+\beta_{6} \ln \mathrm{Er}+\text { et }
$$

\section{Definitions of Variables and Data Source}

This study formulates two equations simultaneously. Equation [3] and [4] are the recursive model linked by the agricultural output variable. In equation [4], agricultural output is the dependent variable, while in equation [3], agricultural output is a component of agricultural wage and used for wage ratio. The model can then be written as:

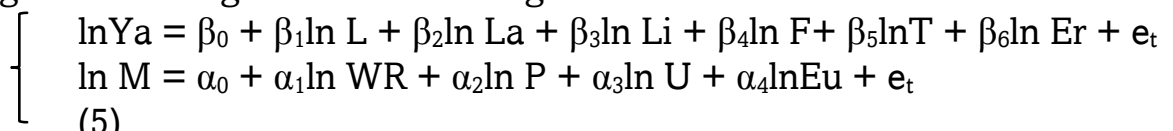

For such equations above, it is suggested to use estimation procedures such as twostage or three stages least squares rather than Ordinary Least Square to avoid biased estimates of the parameters. However, since the equation is a recursive system, using OLS model will not result in bias estimation.

The data and variables are slightly similar with the empirical research conducted by Goldsmith et al (2004) for Senegal case, and Asfaha and Jooste(2006) for South Africa case. All data used in this research cover the year 2010 and the study areas are West Java, Central Java and East Java.

Agricultural output (Ya)- agricultural GRDP of each regency/city at constant price as sourced from BPS (National Statistics) of each province. Agricultural output is measured as the total of crop, livestock, fishery, and forestry production in real terms, expressed in Indonesian Rupiah (IDR).

Labor (La)- the number of agricultural employees in each regency/city as sourced from BPS of each province.

Fertilizer $(F)$ - the number of subsidized fertilizer distribution in agricultural sector in each regency/city as sourced from ministry of agriculture. Fertilizer is measured as the quantity of nitrogen, potassium and phosphorus as well as organic.

Tractor $(\mathrm{T})$ - the number of availability of agricultural equipment and machinery $(2$ wheels tractor) in each regency/city as sourced from ministry of agriculture.

Livestock (Li) - the number of animal units (cattle, buffalo, horses, goats, sheep, chickens, ducks, and pigs) available for agricultural production in each regency/city as sourced from BPS of each province.

Land (L) - the number of wet and dry agricultural land (expressed in hectare) in each regency/city as sourced from BPS of each province. 
Human capital (Er)- the number of university graduates in rural areas in each regency/city as sourced from BPS.

Migration (M) - the number of recent in-migration in urban areas (based on residential five years ago) in each regency/city as sourced from BPS of each province.

Rural population $(\mathrm{Pa})$ - the number of rural population in each regency/city as sourced from BPS.

Urban population $(\mathrm{Pu})$ - the number of urban population in each regency/city as sourced from BPS.

Implicit agricultural wage (Wa) - the ratio of agricultural GRDP to rural population in each regency/city as sourced from BPS of each regency. Agricultural wage is approximated by the average productivity of the family labor force. Family labor is usually the most important cost item for small farms. Traditional agriculture is characterized by work sharing with quasi-unemployment and farm income sharing (Ghatak and Ingerscent, 1984). Thus, according to FAO (1999), the implicit agricultural wage can be defined as the ratio of agricultural output to the total agricultural population. Due to the unavailability of farmers' income data by regency in the country, implicit agricultural wage was used to capture the variable. It can be calculated as:

$$
\mathrm{Wa}=\frac{\mathrm{Ya}}{\mathrm{Pa}}
$$

Implicit urban wage $(\mathrm{Wu})$ - urban wage is defined as non-agricultural output per capita: the ratio of non-agricultural output (GRDP minus agricultural GRDP) to urban population in each regency/city as sourced from BPS of each regency. Here, urban output is equal to the sum of industrial and service production. The implicit urban wage hence is measured as:

$$
\mathrm{Wu}=\frac{\mathrm{Yu}}{\mathrm{Pu}}
$$

Wage ratio (WR)- the ratio of urban wage to agricultural wage.

$$
\mathrm{WR}=\frac{\mathrm{Yu} / \mathrm{Pu}}{\mathrm{Ya} / \mathrm{Pa}}=\frac{\mathrm{Wu}}{\mathrm{Wa}}
$$

Probability of getting an urban job $(\mathrm{P})$ - the number of employment rate (the proportion of urban employment to labor force) in urban areas in each regency/city as sourced from BPS.

Urbanization (U) - the proportion of urban population to total population as sourced from BPS. According to UN, urbanization can be measured by the percentage of urban population or the rate of growth of urban population minus that of the total population.

Education urban $(\mathrm{Eu})$ - the number of university graduates in urban areas in each regency/city as sourced from BPS.

\section{Empirical Result and Interpretation}

There are set of assumptions that need to be met in order to use linear regression. The data has been tested through normality, heteroscedasticity, multicolinearty, and autocorrelation assumption in advance. All variables in agricultural function are normally distributed (significant at 1\% level), no heteroscedasticity and no multicolinearity as well. In agricultural output model, there is no autocorrelation. However, However, from the test result, it cannot be concluded whether there exists autocorrelation or not. The total number of observations is 79. Cities that do not have rural population are excluded from the data. Since all the variables are converted into logarithm form, it can be interpreted as elasticities. Both equations are estimated by Ordinary Least Square (OLS) model. 


\section{Agricultural Output Model}

Table 1. Agricultural Output Model

\begin{tabular}{lrrrr}
\hline \multicolumn{1}{c}{ Variable } & Coefficient & t-statistic & t-probability & VIF \\
\hline Intercept & $16.9550^{\star \star \star}$ & 27.0829 & 0.0000 & 5.055 \\
Labor & $0.1884^{\star \star}$ & 2.1260 & 0.0369 & 1.187 \\
Fertilizer & $0.1993^{\star \star \star}$ & 7.0383 & 0.0000 & 2.041 \\
Tractor & -0.0439 & -1.1042 & 0.2732 & 1.635 \\
Livestock & $0.0719^{\star}$ & 1.7750 & 0.0801 & 4.117 \\
Land & $0.3453^{\star \star \star}$ & 3.8423 & 0.0003 & 4.898 \\
Education rural & $0.2250^{\star \star}$ & 2.3781 & 0.0201 & \\
R-squared & 0.8527 & & & \\
Rbar-squared & 0.8404 & & & \\
Sigma^2 & 0.0810 & & & \\
Durbin-Watson & 1.8576 & & & \\
Observations & 79 & & & \\
\hline
\end{tabular}

* $\mathrm{p}<0.1,{ }^{\star \star} \mathrm{p}<0.05$, *** $\mathrm{p}<0.01$

a) Dependent variable: Agricultural GRDP

In agricultural output equation, the result shows that the labor force coefficient is significant at $5 \%$ level. Thus, it indicates that in Java, additional workers will increase agricultural regional output. A $1 \%$ increase in number of agricultural worker would increase the output by $0.18 \%$. This result is reasonable since the agriculture in Java is more labor intensive rather than capital intensive as the agricultural system is still adopting less technology in the country. Also, the trend of agricultural labor has been decreasing in the past few years. This decline is associated with the increase in land conversion in productive areas (Statistics Indonesia), causing less agricultural land supply. Furthermore, many agricultural workers switch to non-agricultural sector because the prior sector is considered to have no or little adding value and weak competitiveness.

Fertilizer is also statistically significant with agricultural output at $1 \%$ level. A $1 \%$ increase in fertilizer use would increase agricultural output by $0.19 \%$. This result was expected since increased use of fertilizer is associated with the adoption of modern capital and is one of the conditions for increasing productivity. This finding is in line with the study by Kasiyati(2010) who pointed out that subsidized fertilizer in Central Java would increase the production output. In addition, by doing simulation, she also performed that subsidized fertilizer would increase farmers household income by $0.6 \%$. According to World Bank [21], subsidized fertilizer can increase capital availability for farmers. By subsidizing the price of fertilizer, it can facilitate farmers to allocate their money for other inputs. Subsidized fertilizer contributes about $9-22 \%$ of total cost, depending on the dose and technology used. By using subsidized fertilizer, it allows farmers to increase fertilizer dose into the optimal level and it will eventually increase the agricultural productivity.

The tractor coefficient is not significantly different than zero. It is common in developing country, that agricultural mechanization has not been very successfully implemented because agricultural machinery was imported carelessly without any adaptation to the farm condition and characteristics. According to Bachreinet al(2009), in West Java case, generally, farmers use Japanese 2 wheel tractor which is less suitable for the land condition and characteristics.

Livestock also contributes significantly to agricultural output in Java at $10 \%$ level. The result shows that a $1 \%$ increase of livestock would increase agricultural output by $0.1 \%$. It indicates that livestock contributes significantly to agricultural output in the regions. Livestock makes the second major contribution to agricultural GRDP after farm 
food crops in Java. Currently, livestock development has been concentrated in Java, particularly in West Java, Central Java and East Java.

The agricultural land coefficient is significant at 1\% level. A $1 \%$ increase in agricultural land would increase $0.39 \%$ agricultural output. It indicates increase in agricultural land plays an important role in agricultural productivity in Java. This is reasonable since agricultural land in Java is facing an alarming fact on the conversion of agricultural land to non-agro uses. According to Ministry of Agriculture (2005), the conversion rate of the agricultural land in Java Island has reached approximately 100,000 ha per annum. Land conversion has recently been uncontrollable, particularly on irrigated land as well as on agricultural land around cities in Java Island (Adimihardja, 2006). Therefore, developing agricultural land will contribute significantly to boost agricultural productivity considering the output in the present is relatively low due to lack of sufficient land.

The result of education is also significant at $5 \%$ level. A $1 \%$ increase in educational attainment of rural people would increase the agricultural output by $0.2 \%$. Human capital plays an important role in developing agricultural growth in a region. Thus, promoting rural inhabitants' education would result in higher agricultural output.

\section{Migration Model}

Table 2. Migration Model

\begin{tabular}{|c|c|c|c|c|}
\hline Variable & Coefficient & t-statistic & t-probability & VIF \\
\hline Intercept & 1.0023 & 0.1556 & 0.8767 & \\
\hline Wage ratio & $0.3276^{\star \star *}$ & 3.9183 & 0.0002 & 1.450 \\
\hline $\begin{array}{l}\text { Probability of getting } \\
\text { urban job }\end{array}$ & -0.9266 & -0.6525 & 0.5161 & 1.013 \\
\hline Urbanization & $0.8857 * \star \star$ & 5.7659 & 0.0000 & 2.568 \\
\hline Education urban & $0.9219 * * \star$ & 10.0516 & 0.0000 & 1.978 \\
\hline R-squared & 0.8494 & & & \\
\hline Rbar-squared & 0.8412 & & & \\
\hline $\operatorname{Sigma}^{\wedge} 2$ & 0.1632 & & & \\
\hline Durbin-Watson & 1.2841 & & & \\
\hline Observations & 79 & & & \\
\hline
\end{tabular}

a) Dependent variable: Migration

Migration model 1 (see Appendix A) is the estimation of equation [1], where the wages have not been calculated, and does not include urbanization since the equation has already considered urban population. Migration model 2 (see Appendix B) is to estimate equation [2], in which agricultural and urban wage have been computed. The final migration model, equation [3], simplifies the previous equations and all the variables regarding wage have been simplified. In those models, they show that wages, both agricultural and urban, are significant to the migration number. Also, the coefficient signs exhibit that agricultural wage is a negative function of migration to urban areas, while the urban wage is a positive one. It means that as agricultural wage declines, the number of migration to urban areas will likely to increase. Conversely, the migration to urban areas will increase when the urban wage also increases. This result is consistent with the hypothesis; migration is an economical decision when there is a higher expected income in urban areas. Thus, in order to withstand the migration flow to urban areas, one of the alternative ways is to increase agricultural output which will simultaneously increase agricultural wage. 
In migration equation [3], urbanization is positively and significantly correlated at the $1 \%$ level with migration to urban areas. A $1 \%$ increase in urbanization will lower the cost of rural to urban migration, and the number of migration will increase $0.8 \%$. It indicates that as the more urbanized a region, the more inhabitants will be attracted to the urban areas. As region becomes more urbanized and more people reside in urban areas, the number of contacts who live there will also increase. Therefore, urbanization can lower the cost of migration due to the fact that many rural people have contacts living in urban areas, and such contacts would facilitate migration. Moreover, since the cost of migration is lowered, the rural-urban migration rate could increase.

Education level of urban people also plays an important role in migration decision. As urban people achieved higher education, it becomes a pull factor for rural people to migrate to urban areas. A $1 \%$ increase in educational attainment in urban areas would increase migration by $0.9 \%$. Pursuing higher educational attainment attract rural inhabitant because they want to get better and more promising jobs.

Surprisingly, the probability of getting urban job is not statistically different than zero. It indicates that rural-urban migration decision in Java is not affected by the probability of getting an urban job. Although the probability of getting urban job becomes more competitive and limited in Java, it does not affect or withstand rural inhabitant to migrate to urban areas.

\section{Reducing Rural-Urban Migration}

In equation [4], the model estimates agricultural output elasticity to a set of various agricultural inputs. Meanwhile, equation [3] estimates agricultural per capita or income elasticity of rural-urban migration. Therefore, the indirect elasticity of rural-urban migration with respect to agricultural input can be computed through the recursive model [6]. In order to see the impact of agricultural productivity on rural-urban migration, Goldsmith et al(2004) estimated the indirect agricultural input elasticity of migration $\left(\mathrm{E}_{\mathrm{M}, \mathrm{xi}}\right)$. So as to calculate the indirect impact, they multiplied agricultural output of migration $\left(\mathrm{E}_{\mathrm{M}}, \mathrm{wR}\right)$ by the elasticity of agricultural output in response to agricultural input ( $\mathrm{E}_{\mathrm{Ya}} \mathrm{Xi}_{\mathrm{i}}$ ).

By referring to their study, the following equation is used to measure the indirect elasticity impact (see Appendix $C$ for the derivation of equation):

$\left(E_{\mathrm{M}, \mathrm{Xi}}\right)=-\left(\mathrm{E}_{\mathrm{M}, \mathrm{WR}}\right)\left(\mathrm{E}_{\mathrm{Ya}, \mathrm{Xi}}\right)$

From the previous estimation, it is estimated that labor, fertilizer, livestock and land contribute significantly to agricultural output in the study area. By enhancing those agricultural inputs, it is expected to increase the output as well. Thus, these four variables are utilized to calculate the indirect input elasticity of migration.

Table 3. Indirect Agricultural Input Elasticity Of Migration

\begin{tabular}{lccc}
\hline Agricultural Inputs & $\left(\mathrm{E}_{\mathrm{M}, \mathrm{Xi}}\right)$ & $\left(\mathrm{E}_{\mathrm{M}, \mathrm{wR}}\right)$ & $\left(\mathrm{E}_{\mathrm{M}, \mathrm{xi}}\right)$ \\
\hline Labor & 0.1884 & 0.3276 & -0.0617 \\
Fertilizer & 0.1993 & 0.3276 & -0.0653 \\
Livestock & 0.0719 & 0.3276 & -0.0235 \\
Land & 0.3453 & 0.3276 & -0.1131 \\
Education rural & 0.2250 & 0.3276 & -0.0737 \\
\hline
\end{tabular}

By using the equation [9], the result shows that the indirect elasticity of rural-urban migration subject to labor is -0.06 . This indicates that a $1 \%$ increase in agricultural labor would result in $0.06 \%$ decrease in migration to urban areas, keeping all other factors including population constant. So as to increase agricultural labor, creating adequate agricultural related job opportunity is important. In addition, there should be an incentive for rural people so that they are willing to tie up with agricultural sector, and it has to be 
higher than agricultural wage. By increasing the agricultural wage, it will increase the number of agricultural labor, boost agricultural output and eventually reduce migration to urban areas.

The indirect elasticity of rural-urban migration with respect to subsidized fertilizer is -0.06. It implies that a $1 \%$ increase in subsidizing fertilizer in the region would affect migration to decrease by $0.065 \%$. According to World Bank (2009), subsidized fertilizer can increase farmers' capital or asset, suppress distribution price, increase farmers' productivity and enhance farmers' income. However, subsidized fertilizer should be accurately and evenly distributed among each farmer and region. There are several cases where wealthy farmers with larger agricultural land receive more subsidized fertilizer than poor and less spacious farmers because farmers with larger land use more fertilizer.

Livestock variable appears to have the slightest indirect elasticity to migration. A $1 \%$ increase in livestock will have impact on declining migration by $0.02 \%$. Livestock has the least contribution to increase agricultural output compare to other variables. Thus, increasing or adding the number of domestic animals so as to reduce migration number to urban areas seems does not have significant effect.

As for agricultural land, it has the biggest impact to reduce migration to urban areas. A $1 \%$ increase in agricultural land would result in $0.11 \%$ decrease in rural-urban migration. However, because agricultural land in Java is limited and supply of land is fixed, reducing rural-urban migration through land extensification in the long-term may not be possible. Thus, land intensification is more preferred in this area. In this sense, improving the utilization of existing agricultural land and enhancing its productivity becomes crucial to reduce migration to urban areas in the regions. However, one should be discreet and more concern for the smallholders in utilizing agricultural land. White [18] stated that in Javanese agriculture, instead of reducing migration, agricultural modernization has been found to stimulate migration to urban areas, particularly for smallholder farmers. It occurs because green revolution is only benefiting farmers who have extensive land in receiving technology (capital intensive). Thus, it gives rise to social polarization in rural inhabitants causing many rural people leave rural areas due to the limited agricultural job opportunity.

For the impact of education in rural areas, a $1 \%$ increase in rural people education will reduce the migration to urban areas by $0.07 \%$. Nevertheless, pursuing higher education is kind of problematic for rural people. At one side, better educated rural inhabitant will have a chance to increase agricultural output. On the other side, education can also be a potential factor to enter urban areas. Thus, for keeping rural people to develop agricultural productivity in rural areas, it has to be the case in which there is sufficient agricultural related job opportunity. By doing so, rural people are willing to attach to agricultural sector and promote it. If there is lack of agricultural related job opportunity in the rural areas, for instance due to limited agricultural land, rural people will choose to enter urban areas. Therefore, utilizing agricultural land, upgrading rural services and facilities, and creating sufficient and promising jobs in rural areas are inevitably necessary to withstand migration flow to urban areas.

\section{Conclusion}

The focus of this paper is to estimate the impact of agricultural output on in migration, particularly in regencies and small cities in three provinces in Java Island. Here, improving agricultural productivity targeted in key areas can make a good contribution to reduce rural-urban migration and expansion of urbanization. By means of improving agricultural productivity, it is expected that the urban-rural income differentials can be minimized, and thus the number of migration can be reduced eventually. The estimation suggests that through increasing fertilizer use, adding agricultural labor and livestock, increasing educational attainment of rural inhabitant, as well as utilizing agricultural land 
and enhancing its productivity would expect to increase agricultural output. By way of increasing this agricultural output, it is expected to boost rural income, and hence narrow the wage differential between urban and rural area. However, to lessen the bias of benefiter of such agricultural development policy, it should be implemented and distributed evenly to all types of farmers, particularly to the smallholders. To support the policies, upgrading rural services and facilities, and creating sufficient and promising jobs in rural areas are inevitably important to withstand migration flow to urban areas.

In order to cope with migration in urban areas, one needs to focus on rural policy issues rather than solely focusing on the policy for urban poverty problems. By minimizing the income disparities between urban and rural labor, it could reduce the migration flow to urban areas. Nevertheless, one should be aware that this response depends on how successful the effects of agricultural investment can boost the production and hence reduce the wage differential. Also, the investment has to be taken into account conscientiously in order to increase the agricultural output. If the investment fails to boost production, the effect could be the case that the increase in agricultural investment does not necessarily result in increase in agricultural output due to many shortcomings.

\section{Appendix A}

Table 4. Migration By Ols Model 1

\begin{tabular}{|c|c|c|c|c|}
\hline Variable & Coefficient & t-statistic & t-probability & VIF \\
\hline Intercept & -8.5556 & -1.0169 & 0.3126 & \\
\hline $\begin{array}{l}\text { Probability of } \\
\text { getting urban job }\end{array}$ & 1.7156 & 1.0009 & 0.3202 & 1.371 \\
\hline Rural population & 0.0706 & 0.6592 & 0.5119 & 3.633 \\
\hline Urban population & $0.5763^{\star \star \star}$ & 3.3195 & 0.0014 & 7.751 \\
\hline Agricultural GRDP & $-0.3682^{\star \star \star}$ & -2.9099 & 0.0048 & 3.610 \\
\hline $\begin{array}{l}\text { Non-agricultural } \\
\text { GRDP }\end{array}$ & $0.2389 \star \star$ & 2.2413 & 0.0281 & 3.824 \\
\hline Education urban & $0.5376^{\star \star}$ & 2.8030 & 0.0065 & 8.041 \\
\hline R-squared & 0.8423 & & & \\
\hline Rbar-squared & 0.8292 & & & \\
\hline $\operatorname{Sigma}^{\wedge} 2$ & 0.1756 & & & \\
\hline Durbin-Watson & 1.3005 & & & \\
\hline Observations & 79 & & & \\
\hline
\end{tabular}

a) Dependent variable: Migration

\section{Appendix B}

Table 5. Migration By Ols Model 2

\begin{tabular}{lrrrr}
\hline \multicolumn{1}{c}{ Variable } & Coefficient & t-statistic & t-probability & VIF \\
\hline Intercept & -8.5556 & -1.0169 & 0.3126 & 1.371 \\
Probability of & 1.7156 & 1.0009 & 0.3202 & 3.633 \\
getting urban job & & & & 0.5119 \\
Rural population & 0.0706 & 0.6592 & 0.0014 & 3.751 \\
Urban population & $0.5763^{\star \star \star}$ & 3.3195 & 0.0048 & 3.824 \\
Agricultural GRDP & $-0.3682^{\star \star \star}$ & -2.9099 & 0.0281 & 8.041 \\
Non-agricultural & $0.2389^{\star \star}$ & 2.2413 & & 0.0065 \\
GRDP & & & & \\
Education urban & $0.5376^{\star \star}$ & 2.8030 & & \\
R-squared & 0.8423 & & & \\
Rbar-squared & 0.8292 & & & \\
Sigma^2 & 0.1756 & & & \\
\hline
\end{tabular}




\begin{tabular}{lrrrr}
\hline \multicolumn{1}{c}{ Variable } & Coefficient & t-statistic & t-probability & VIF \\
\hline Durbin-Watson & 1.3005 & & & \\
Observations & 79 & & & \\
\hline
\end{tabular}

* $p<0.1,{ }^{\star *} p<0.05,{ }^{\star * \star} p<0.01$

a) Dependent variable: Migration

\section{Appendix C}

Given that $\mathrm{M}=\mathrm{f}(\mathrm{WR}), \mathrm{WR}=\mathrm{g}(\mathrm{Ya})$ and $\mathrm{Ya}=\mathrm{h}(\mathrm{Xi})$, the derivation of indirect elasticity $\left(\mathrm{E}_{\mathrm{M}, \mathrm{Xi}}\right)$ of migration $(\mathrm{M})$ with respect to agricultural input $(\mathrm{Xi})$ is:

$E_{M, X i}=\left\{\frac{d M}{d W R} \frac{d W R}{d Y a} \frac{d Y a}{d X i}\right\} \frac{X i}{M}$

$=\left\{\left(\frac{d M}{d W R} \frac{W R}{M}\right) \frac{M}{W R}\left(\frac{d W R}{d Y a} \frac{Y a}{W R}\right) \frac{W R}{Y a}\left(\frac{d Y a}{d X i} \frac{X i}{Y a}\right) \frac{Y a}{X i}\right\} \frac{X i}{M}$

$=\left\{\left(E_{M, W R} \frac{M}{W R}\right) E_{W R, Y a}\left(\frac{W R}{Y a}\right)\left(E_{Y a, X i} \frac{Y a}{X i}\right)\right\} \frac{X i}{M}$

$=\left(E_{M}, w R\right)\left(E_{W R, Y a}\right)\left(E_{Y a}, X_{i}\right)\left(\frac{M}{W R} \frac{W R}{Y a} \frac{Y a}{X i} \frac{X i}{M}\right)$

$=\left(E_{M}, W R\right)\left(E_{W R, Y a}\right)\left(E_{Y a}, X_{i}\right)$

$\mathrm{WR}=\left(\frac{\mathrm{Yu} / \mathrm{Pu}}{\mathrm{Ya} / \mathrm{Pa}}\right)=\left(\frac{\mathrm{Yu}}{\mathrm{Ya}} \frac{\mathrm{Pa}}{\mathrm{Pu}}\right)$

By assumption,

$$
E_{W R, Y a}=\left(\frac{d W R}{d Y a} \frac{Y a}{W R}\right)=\left(\frac{d\left(\frac{Y u}{Y a} \frac{P a}{P u}\right)}{d Y a}\right)\left(\frac{Y a}{\frac{Y u}{Y a} \frac{P a}{P u}}\right)=-1
$$

substituting -1 in equation $\left(\mathrm{E}_{\mathrm{M}, \mathrm{WR}}\right)\left(\mathrm{E}_{\mathrm{WR}, \mathrm{Ya}}\right)\left(\mathrm{E}_{\mathrm{Ya}} \mathrm{Xi}\right)$, it follows that:

$\mathrm{E}_{\mathrm{M}, \mathrm{Xi}}=\left(\mathrm{E}_{\mathrm{M}, \mathrm{wR}}\right)(-1)\left(\mathrm{E}_{\mathrm{Ya}, \mathrm{Xi}}\right)$

$E_{M, X i}=-\left(E_{M}, w R\right)\left(E_{Y a, X i}\right)$

\section{References}

Adimihardja, A. 2006. Strategy for Maintaining the Multifunctionality of Agriculture in Indonesia. Indonesian $\begin{array}{llll}\text { Agricultural } & \text { Research } \text { and Development } & \end{array}$ http://balittanah.litbang.deptan.go.id/dokumentasi/prosiding/mflp2006/a adi.pdf

Asfaha, T. A. \&Jooste, 2006. A.The Agricultural Input Elasticity of Rural-Urban Migration in South Africa.Agrekon, 45 (1), pp. 89-105. http://purl.umn.edu/31736

Bachrein, S., Ruswandi, A., \&Subarna, 2009. T.The Usage of Two Wheels Tractor in Paddy Land in West Java.Agricultural Journal, 20 (3), pp. 190-197

Bhattacharya, P. C. 2002. Rural to Urban Migration in LDCS: A Test of Two Rival Models. Journal of International Development, 14, pp. 951-972.. http://hdl.handle.net/10.1002/jid.915

Byerlee, D. 1974. Rural-Urban Migration in Africa: Theory, Policy and Research Implications. International Migration Review, 8 (3), pp. 543-566. http://www.jstor.org/stable/3002204

Chen, N., Valante, P., \& and H. Zlotnik. 1996. What do we know about Recent Trends in Urbanization? Migration, Urbanization, and Development: New Directions and Issues ed. R.E. Bilsborrow. UN Population Fund and Kluwer Academic Publishers.

Dillon, J and L, Hardaker, J. B. 1993. Farm Management Research for Small Farmer Development. FAO Farm System Management Series, 6, Rome.

Ghatak, S., \&Ingerscent, K. 1984. Agriculture and Economic Development. John Hopkins University Press, Maryland.http://www.jstor.org/stable/143562

Goldsmith P.D, Gunjal K \&Ndarishikanye B. 2004. Rural-Urban Migration and Agricultural Productivity: The Case of Senegal. Agricultural Economics 31(1), pp. 33-45. http://EconPapers.repec.org/RePEc:eee:agecon:v:31:y:2004:i:1:p:33-45 
Gosh, J. 2012. The Challenges of Urbanisation May Be Even Greater in Small Town. 2 October. http://www.guardian.co.uk/global-development/poverty-matters/2012/oct/02/challenges urbanisation-greater-small-towns

Hanmer, L., \&Naschold, F. 2000. Attaining the International Development Targets: Will Growth Be Enough? Development Policy Review, 18(1), pp. 11-36.http://dx.doi.org/10.1111/1467-7679.00098

Harris, J. R., \&Todaro, M.P. 1970. Migration, Unemployment and Development: A Two Sector Analysis. American Economic Review. 60 (1), pp. 126-138. http://www.jstor.org/stable/1807860

Hugo, G.J. 2000. The Crisis and International Population Movements in Indonesia.Asian Pacific Migration Journal 9 (1), pp. 93-129.

Kasiyati, S. 2010. The Impact of Subsidized Fertilizer towards Production Sector Output and Household Income in Central Java Analysis. Organization and Management Journal, 6 (1), pp. 28-45. eprints.undip.ac.id/17649/

Mellor, J. 2001. Reducing Poverty, Buffering Economic Shocks - Agriculture and the Non-Tradable Economy.Paper prepared for FAO consultation on the Roles of Agriculture in Development, 19-21 March 2001, Rome.

Stiglitz, J. 1969. Rural-Urban Migration, Surplus of Labor and the Relationship between Urban and Rural Wages. East Africa Economic Review, 2, pp. 1-28.

Thirtle, C., Lin, \&Piesse, 2003. J.The Impact of Research Led Agricultural Productivity Growth On Poverty Reduction in Africa, Asia and Latin America. World Development 31 (12), pp.1959-1975. http://www.sciencedirect.com/science/article/pii/S0305750X03001682

White, B. 1979. Political Aspects of Poverty, Income Distribution and their Measurement: Some Examples from Rural Java. Development and Change, 10, pp.91-114. http://dx.doi.org/10.1111/j.14677660.1979.tb00032.x

Winoto, J., \&Siregar, H. 2008. Agricultural Development in Indonesia: Current Problems, Issues, and Policies. Agricultural Policy Analysis, Vol. 6, No. 1, March 2008: 11-36. pse.litbang.deptan.go.id/ind/pdffiles/ISU6-1b.pdf

World Bank. 2008. World Development Report: Agriculture for Development.

World Bank. 2009.Indonesia Agricultural Public Spending and Growth, Policy Note. Indonesia Agriculture Public Expenditure Review, the World Bank, Jakarta.

Zhang, K. H., \& Song, S. 2003. Rural-Urban Migration in China: Evidence from Time-Series and Cross-Section $\begin{array}{lllll}\text { Analysis. China } & \text { Economic } & \text { Review, } & \text { 386-400. }\end{array}$ http://www.sciencedirect.com/science/article/pii/S1043951X03000695 